CONSIDERACIONES GENERALES SOBRE LOS CONCEPTOS DE PATRIA POTESTAS, FILIUS-, PATER-, Y MATERFAMILIAS: UNA APROXIMACIÓN AL ESTUDIO DE LA FAMILIA ROMANA

Mª Luisa LÓPEZ HugueT

Invesgitadora

UNIVERSIDAD DE LA RIOJA

s $u$ m a r i o

I. Introducción. II. Sobre los conceptos patria potestas, filius-, y paterfamilias. III. Diferencia entre matrimonium y conventio in manum. IV. Análisis de los diversos significados del concepto materfamilias. V. Regulación actual y conclusión.

$r$ e $\mathrm{s} u$ m e $n$

La relación paterno-filial podía constituirse ex iure al margen biológico de la procreación. La patria potestas otorgaba al paterfamilias unos omnímodos poderes sobre sus subiecti que se fueron dulcificando como consecuencia del paso de la familia agnaticia a la cognaticia, la mayor capacidad patrimonial de los filii vía peculios y el proceso de emancipación femenina, en virtud del cual el matrimonium dejó de estar acompañado de la conventio in manum que integraba a la esposa en el grupo agnaticio-familiar del marido. La estrecha relación entre ambos institutos hasta mediados de la República generó en la doctrina la errónea opinión de la existencia de dos tipos de matrimonio en Roma, uno cum manu y otro sine manu, reservando el calificativo de materfamilias a la esposa in manum mariti.

\title{
I. Introducción.
}

En ocasiones, estamos tan acostumbrados al empleo de determinados términos jurídicos que terminamos olvidando el originario y primitivo significado de los mismos. Así sucede, entre otros, con los conceptos de patria potestad, hijo, padre o madre de familia, expresiones frecuentes, comunues y habituales en nuestra vida cotidiana sobre las que, sin embargo, conviene volver a reflexionar. 
Éste va ser el objeto de nuestro trabajo, tratar de perfilar, sin pretensiones de exhaustividad, las raíces de tales conceptos, herederos, como tantas instituciones propias de nuestro ordenamiento jurídico, del ancestral Derecho Romano, en el firme convencimiento demostrado por el profesor FERNÁNDEZ DE BUJÁN, A., de que «sólo desde la consideración del Derecho como un agregado lógico e histórico de experiencias colectivas, podrán no sólo valorarse e interpretarse más adecuadamente las normas jurídicas, sino también abordarse la antigua y permanente aspiración de construir una ciencia del derecho de carácter supranacional».

II. Sobre los conceptos patria potestas, filius-y paterfamilias.

Es aceptado de forma unánime por la doctrina romanística que el status del filiusfamilias legítimo se encontraba extrictamente ligado a la organización de la familia y de la patria potestas ${ }^{2}$, un ius propium civium romanorum ${ }^{3}$ que se proyectaba sobre los descendientes por quien lo ostentaba (parterfamilias-sui iuris) y que condicionaba la vida de aquéllos (alieni iuris), fundamentalmente en el ámbito del Derecho privado ${ }^{4}$, hasta su desaparición sin límite de edad o posición pública.

I Fernández de Buján, A., Derecho Público Romano. Recepción, Jurisdición y Arbitraje, $8^{\mathrm{a}}$ edición, Madrid, 2005, prólogo a la primera edición, pág. I3. Esta idea ha sido ampliamente acogida por la doctrina, entre otros, Alburquerque, J.M., La protección o defensa del uso colectivo de las cosas de dominio público: Especial referencia a los interdictos de publicis locis (loca, itenere, viae, flumina, ripae), Madrid, 2002, págs. 27-28; AGUDO RUIZ, A., Régimen jurídico del tesoro en Derecho romano, 2005, pág. I9.

${ }^{2}$ La determinación del status del filiusfamilias a través de la patria potestas es afirmada por Bonfante, P., Corso di Diritto romano, Volume primo, Diritto di famiglia, Milano, I963 (reimpresión corregida de la primera edición de Milano, I925), pág. I8; BUCKLAND, W.W., $A$ manual of roman privat law, Aalen, I98I (reimpresión de la $2^{a}$ edición de Cambridge, I953), pág. 62; Lobrano, G., Pater et filius eadem persona -Per lo studio della patria potestas-, I, Milano, I984, págs. I46 ss.; TAFARO, S., La pubertà a Roma. Profili giuridici, Bari, I993, pág. I4; SANSÓN RODRÍGUEZ, Ma.V., «La posesión constante del estado de hijo legítimo», en MURILLO VILLAR, A., (Coord.), Estudios de Derecho romano en memoria de Benito M . Reimundo Yanes, II, Burgos, 2000, págs. 465 ss.; PERIÑÁn GómeZ, B., Antecedentes y consecuencias del SC. Macedoniano, Valencia, 2000, págs. 9I Ss.

3 GAYO, Institutae, I.55: «Item in potestate nostra sunt liberi nostri, quos iustis nuptiis procreauimus. Quod ius proprium ciuium Romanorum est (fere enim nulli alii sunt homines, qui talem in filios suos habent potestatem, qualem nos habemus/»; Institutae, I.I28; Institutiones, 3.56; Dionisio de Halicarnaso, Antiquitates Romanae, 2.25 .6 y 2.26-27; Collatio Legum Romanorum et Mosaicorum, 4.8.I; Dión Crisótomo, Oratio, I5. Por todos, DEvillA, G.M., Il carattere della famiglia ed il regime patrimoniale dei coniugi, Parte prima, Volume I, Sassari, I885, pág. I70; RIVIER, A., Précis du Droit de famille romain, Paris, I89I, págs. 50-52; PARIBENI, R., La famiglia romana, $4^{a}$ edición, Bologna, I948, pág. 33; CASTELlO, C., «Il cosidetto ius migrandi dei latini a Roma. Ricerche in tema di concessione e accertamento degli status civitatis et familiae del 338 al 95 AV.C.», en Bulletino dell'Istituto di Diritto Romano, LXI-LXII, I958, pág. 229, págs. 233-235 y págs. 26I-262; FERNÁNDEZ DE BUJÁN, A., El filiusfamilias independiente en Roma y en el Dercho español, $2^{a}$ edición, Madrid, I98I, pág. 2 I.

${ }^{4}$ Esta relación paterno-filial, se enmarca fundamentalmente en el ámbito del Derecho privado porque la condición de ciudadanos romanos determinaba que, en líneas generales, pater et filius se encontrasen en la esfera pública en un plano de igualdad. RIVIER, Précis du Droit de famille romain, cit., págs. 83 ss., para quien la potestad no influye sobre los derechos políticos del hijo; BonfANTE, Corso di Diritto romano, Volume primo, cit., pág. Io y pág. 93; AlBANESE, B., Le persona nel Diritto privato romano, Palermo, I979, págs. 246-247; GALLO, F., «Idee vecchie e nuove sui poteri del «pater familias», en AA. VV., Poteri negotia actiones nella esperienza romana arcaica (Atti del convegno di diritto romano Copanello I2-I5 maggio I982), Napoli, I984, pág. 48; NERAUDAU, J.P.,

Redur 4 / 2006 
El paterfamilias, afirma ALBANESE, adquiría la patria potestas sobre todos los hijos nacidos del matrimonium iustum, pudiendo reconocer su legítima pertenencia a la familia (ius tollendi) o rechazarlos (ius exponendi $)^{5}$. Sin embargo, la misma podía constituirse al margen del hecho biológico de la procreación dado que, como precisa FERNÁNDEZ DE BUJÁN, A., paterfamilias era todo aquel cives no sometido a la potestas de otro con independencia de que tuviera descendencia 0 no ${ }^{6}$. Por ello se podía adquirir el status de

Être enfant à Rome, Paris, I984, págs. I49 Ss.; LACEY, W.K., «'Patria potestas'», en RAWSON, B., (Ed.), The Family in ancient Rome. New perspectives, London, I992, pág. I27; FRANCIOSI, G., Famiglia e persone in Roma antica. Dall'età arcaica al Principato, Torino, I992, págs. 46-47; TAFARo, La pubertà a Roma, cit., pág. 48 n. 54; GARDNER, J.F., Being a Roman Citizen, London-New York, I993, págs. 79 ss.; FAYER, M.C., La familia romana. Aspetti giuridici ed antiquiari, Parte prima, Roma, I994, págs. I35 ss.; DuCos, M., Roma e il Diritto, (trad. de R. Ferrara), Bologna, I998, págs. 44-45; PERIÑÁn GómeZ, Antecedentes y consecuencias del SC. Macedoniano, cit., pág. 9i. Cfr. LATORRE, A., «Sobre la capacidad jurídica de Derecho público del 'filius familias'», en AA.VV., Estudios jurídicos en homenaje al profesor Ursicino Álvarez Suárez, Madrid, I978, págs. 25I ss., donde refleja el conflicto que, en ocasiones, se produce entre ambos ámbitos; MORDECHAI RABELLO, A., Effetti personali della "patria potestas», I, Dalle origini al periodo degli Antonini, Milano, I979, pág. I35, para quien el contraste entre el ámbito público y privado del hijo es teórico ya que el mismo solía continuar la política del padre.

${ }^{5}$ Albanese, Le persone nel Diritto privato romano, cit., pág. 213 y pág. 2I8; DALL'Olio Romano, J.G., Elementi delle leggi civili romane, I, $3^{\text {a }}$ edición, Faenza, I803, págs. 49 ss.; DECLAREUIL, J., «Paternité et Filiation legitimes», en Mélanges Girard: Études de Droit Romain dédices à Girard, I, Paris,I9I2, págs. 3I5-352; COSTA, E., Storia del diritto romano privato dalle origini alle compilazioni giustinianee, $2^{\text {a }}$ edición, Torino, I925, págs. 7I SS.; PARIBENI, La famiglia romana, cit., pág. 30; LANFRANCHI, F., «Prospettive vecchie e nuove in tema de filiazione», en Studi in memoria di Albertario, I, I953, págs. 74I ss.; VOlTERRA, E., su voz «filiazione (Diritto romano)», en Novissimo Digesto Italiano, VII, Torino, I96I, págs. 308 ss.; idem, «Un osservazione in tema di 'tollere liberos'», en Scritti Giuridici, II, Famiglia e Successioni, Napoli-Paris, I991, págs. 2I7 ss.; CASTELLO, C., «Tre norme speciali romane in tema di filiazione», en Annali Genova, 2, 1962, págs. 292 ss., donde junto a la regla general, recoge suspuestos especiales de filiación; PECORELLA, C., su voz «filazione (Storia)», en Enciclopedia del Diritto, XVII, Milano, I968, págs. 449 ss.; FUSTEL DE Coulanges, La ciudad antigua. Estudio sobre el Culto, el Derecho y las Instituciones en Grecia y Roma, México, I978, pág. 34; CAPOGROSSI Colognesi, L., su voz «patria potestà (Diritto romano)», en Enciclopedia del Diritto, XXXII, Milano, I982, págs. 247-248; RomANO, A., «'Tollere liberos': uomo, donna e potree», en Sodalitas in onore di Guarino, II, Napoli, I984, págs. 88I ss.; TAFARO, La pubertà a Roma, cit., pág. I92 n. I5; DIXON, S., The Roman Family, London, I992, pág. IOI; FrAnciosi, Famiglia e persone in Roma antica. Dall'età arcaica al Principato, cit., págs. 58-59; SANSÓN RODRÍGUEZ, «La posesión constante del estado de hijo legítimo», cit., págs. 472 ss. Las mujeres sui iuris estaban privadas de la patria potestad, pero se les permitió en el derecho postclásico la adopción. Al respecto, FAYER, La familia romana, cit., pág. I9; DUCOS, Roma e il Diritto, cit., pág. 44; RAWSON, B., «Adult-Child Relationships in roman society», en RAWSON, B., (Ed.), Marriage, Divorce and Children in ancient Rome, Oxford, I996, pág. I2; LóPEZ RoSA, R., «Familia y Matrimonio: a propósito de la organización social y política en la Roma antigua», en AA.VV., Libro homenaje In memoriam de Carlos Díaz Rementaria, Huelva, I998, pág. 4I7; PERIÑÁN GómEZ, Antecedentes y consecuencias del SC. Macedoniano, cit., pág. 93. Cfr. D. 50.16.195『5 (Ulpianus libro XLIII. Ad Edictum): «Mulier autem familiae suae et caput, et finis est».

${ }^{6}$ Fernández de Buján, Derecho Público Romano. Recepción, Jurisdicción y Arbitraje, cit., págs. 65-66; idem, «Reflexiones a propósito de la realidad social, la tradición jurídica y la moral cristiana en el matrimonio romano (I)», en Revista General de Derecho Romano, www.iustel.com, $\mathrm{n}^{\circ}$ 6, 2006, págs. I-8; Bonfante, Corso di Diritto romano, Volume primo, cit., págs. II Ss.; FUSTEL DE Coulanges, La ciudad antigua. Estudio sobre el Culto, el Derecho y las Instituciones en Grecia y Roma, cit., págs. 6I-62; ALBANESE, Le persone nel Diritto privato romano, cit., págs. 2I2-213; NERAUdAu, Etre enfant à Rome, cit., pág. I59; DIXON, The Roman Family, cit., pág. 2; GARDNER, Being a Roman Citizen, cit., pág. 4 y págs. 52 ss.; FAYER, La familia romana, cit., pág. I8, apunta que pater no significa progenitor sino jefe de familia; DuCOS, Roma e il Diritto, cit., págs. 43-44; LÓPEZ RosA, «Familia y Matrimonio: a propósito de la organización social y política en la Roma antigua», cit., pág. 4I7; PERIÑ̂́N GómEZ, Antecedentes y consecuencias del SC. Macedoniano, cit., pág. 94.

Redur 4 / 2006 
filiusfamilias ex iure, es decir, a través de un acto jurídico como la adoptio ${ }^{7}$ la adrogatio ${ }^{8}$ o la conventio in manum 9 y conservarlo si tras la muerte o capitis deminutio del pater, el subiectus tenía un ascendiente masculino en línea recta que sí quedaba liberado y asumía el status de paterfamilias sobre sus descendientes ${ }^{\mathrm{IO}}$.

Por tanto, podemos definir al filius/filiaefamilias legítimo, como todo ciudadano romano, hombre o mujer, sujeto a la patria potestas de un paterfamilias con independencia del hecho biológico de la procreación hasta que la misma cese $^{\mathrm{II}}$, siempre que no tenga

\footnotetext{
${ }^{7}$ La adoptio es, en sentido estricto, la adopción de un sujeto alieni iuris. DALL'Olio RomANO, Elementi delle leggi civili romane, cit., págs. 88 ss.; RIVIER, Précis du Droit de famille romain, cit., págs. 64 ss.; CoRnIL, C., Droit Romain, Bruxelles, I92I, págs. I38 ss. y págs. 562 ss.; DE RUGGIERO, E., La patria nel diritto pubblico romano, Roma, I92I, págs. 86 ss.; CosTA, Storia del diritto romano privato dalle origini alle compilazioni giustinianee, cit., págs. 59 ss.; CollineT, P.-GIFFARD, A., Précis de Droit Romain, I, Paris, I930, págs. I82 ss.; ARCHI, G.G., L'«Epitome Gai», Napoli, I99I (reimpresión de la edición de Milano, I937), págs. I49 ss.; BRANCA, B.G., su voz «adozione (Diritto romano)», en Enciclopedia del Diritto, Milano, I958, págs. 579 ss.; BonfANTE, Corso di Diritto romano, Volume primo, cit., págs. I8 ss. y págs. 37 ss.; CASTELLO, C., «Sui principii ispiratori delle norme sull'età dell'adottante e dell'adottato in Diritto romano», en Studi in onore di Giuseppe Grosso, IV, Torino, I968, págs. I93 ss.; HoRVAT, M., «Les aspects sociaux de l'adrogation et de l'adoption à Rome», en Studi in onore di Giuseppe Grosso, VI, Torino, I968, págs. 45 ss.; AlbANESE, Le persone nel Diritto privato romano, cit., págs. 228 ss.; MORDECHAI RABELLO, Effetti personali della "patria potestas», cit., pág. 3I, pág. 68, págs. I24 Ss. y pág. I8I, entre otras; BuCKLAND, $A$ Manual of roman private law, cit., págs. 74 Ss.; NARDI, E., «Poteva la donna, nell'Impero romano, adottare un figlio?», en Studi in onore di Arnaldo Biscardi, I, Milano, I982, págs. I97 SS.; RUSSO RUGGERI, C., La datio in adoptionem, I, Origine, Regime giuridico e riflessi politico-sociali in età repubblicana ed imperiale, Milano, I990, passim; idem, La datio in adoptionem, II, Dalla pretesa influenza ellenocristiana alla riforma giustinianea, Milano, I995, passim; FRANCIOSI, Famiglia e persone in Roma antica. Dall'età arcaica al Principato, cit., págs. $6_{3}$ ss.; KNÜTEL, R., Skizzen zum römischen Adoptionsrecht: «Plena pubertas', Annahme an Enkels Statt, Erhaltung der Mitgift», en Index, 22, I994, págs. 249 ss.; FAYER, La familia romana, cit., págs. 29I ss.; CoRBIER, M., «Divorce and Adoption as Roman Familial Strategies (Le Divorce et l'adoption 'en plus')», en RAWSON (Ed.), Marriage, Divorce, and Children in ancient Rome, cit., págs. 63 ss.; D’ORs, A., Derecho Privado romano, 9 a edición, Pamplona, I997, págs. 289 ss.

${ }^{8}$ La adrogatio suponía que un parterfamilias se sometía a la potestad de otro paterfamilias pasando a ser alieni iuris de éste. CoRnIL, Droit Romain, cit., págs. I38 ss. y págs. 562 ss.; CosTA, Storia del diritto romano privato dalle origini alle compilazioni giustinianee, cit., págs. 63 ss.; Collinet - Giffard, Précis de Droit Romain, I, cit., págs. I83-I84; ARCHI, L'«Epitome Gaì, cit., págs. I49 ss.; Bonfante, Corso di Diritto romano, Volume Primo, cit., págs. 20 ss. y págs. 45 ss.; HORVAT, «Les aspects sociaux de l'adrogation et de l'adoption à Rome», cit., págs. 45 ss.; ALBANESE, Le persone nel Diritto privato romano, cit., págs. 2I8 ss.; MORDECHAI RABELLO, Effetti personali della "patria potestas», cit., pág. 67; BuCKLAND, A manual of roman private law, cit., págs. 74 ss.; FrAnciosi, Famiglia e persone in Roma antica. Dall'età arcaica al Principato, cit., págs. 6o ss.; FAYER, La familia romana, cit., págs. 29I ss.; D'ORS, Derecho Privado romano, cit., págs. 289 ss.; ARENDS Olsen, L., La femme et l'enfant dans le unions illégitimes à Rome. L'evolution du droit jusqu'au début de l'Empire, Bern, Berlin, Bruxelles, Frankfurt a. M, New York, Wien, I999, pág.
} IO०.

${ }^{9}$ Sobre la conventio in manum vid. infra.

${ }^{\text {Io }}$ Gayo, Institutae, I.I33: «Admonendi autem sumus liberum esse arbitrium ei, qui filium et ex eo nepotem in potestate habebit, filium quidem de potestate dimittere, nepotem uero in potestate retinere: uel ex diuerso filium quidem in potestate retinere, nepotem uero manumittere, uel omnes sui iuris efficere, eadem et de pronepote dicta esse intellegemus». BonfANTE, Corso di Diritto romano, Volume primo, cit., págs. iI ss.; ALBANESE, Le persone nel Diritto privato romano, cit., págs. 2 I6 ss.; DiXON, The Roman Family, cit., pág. 2 y pág. 4I; FRANCIOSI, Famiglia e persone in Roma antica. Dall'età arcaica al Principato, cit., págs. 67-68; FAYER, La familia romana, cit., págs. 20-2I; PERIÑÁn SAlGAdo, Antecedentes y consecuencias del SC. Macedoniano, cit., págs. 93-95.

${ }^{\text {II }}$ Por ejemplo, la patria potestas podía concluir mediante la emancipatio. Por todos, BONFANTE, Corso di Diritto romano, Volume primo, cit., págs. 78 ss. Asimismo, según GAYo, Institutae, I.I3I,

Redur 4 / 2006 
ascendientes masculinos en línea recta ni se someta, de otro modo, a la patria potestas de un nuevo paterfamilias.

El carácter patriarcal, patrilineal, potestativo y agnaticio de esta primitiva familia romana, indica FERNÁNDEZ DE BUJÁN, A., comportó que en los primeros siglos de la sociedad romana, el paterfamilias fuese el titular de los derechos y el representante de todas las personas sometidas a su potestad, ejerciendo sobre ellos un poder semejante al que ostentaba el rex sobre sus ciudadanos, salvo los límites consuetudinarios establecidos por las costumbres ancestrales (mores maiorum) y por la ritual consulta al tribunal doméstico. Tanto es así, que se integraban dentro de la patria potestad no sólo los ya citados ius tollendi y exponendi, sino también, el ius vitae et necis, que permitía al pater familias decir sobre la vida o la muerte de su filius, el ius vendendi, que consentía su venta y el ius noxae dandi, en virtud del cual podía expirar la responsabilidad derivada de un ilícito cometido por su sometido entregándolo al perjudicado ${ }^{\mathrm{I} 2}$.

antiguamente, aquél que se trasladaba a una colonia latina, con el consentimiento de su padre, no sólo perdía la ciudadanía romana, sino que también dejaba de estar en la potestad paterna porque se hacía ciudadano de otra comunidad. Esta unión entre el status civitae y el status familiae se observa, a su vez, en otro pasaje gayano citado supra n. 3 (Institutae, I.128) relativo a las consecuencias de la aquae ignique interdictio. De acuerdo con el jurisconsulto, si un pater perdía la ciudadanía romana por capitis deminutio, sus sometidos devenían sui iuris porque era un contrasentido que un hombre de condición extranjera tuviera en su potestad a un ciudadano romano. Y por la misma razón, si la interdicción se irrogaba a un alieni iuris, éste dejaba de estar sometido a potestad porque también resultaba un contrasentido que un hombre de condición extranjera estuviera sometido a la potestad de un paterfamilias romano. CASTELLO, «Il cosidetto 'ius migrandi' dei latini a Roma», cit., págs. 233-234; DE Dominicis, M.A., su voz, «latini», en Novissimo Digesto Italiano, IX, Torino, I963, pág. 464 n. 2I; DE MARTino, F., Storia della Costituzione romana, II, 2a edición, Napoli, I973, pág. 98 n. 65.

I2 FERNÁNDEZ DE BUJÁN, El filiusfamilias independiente en Roma y en el Derecho español, cit., págs. 2I ss.; idem, «Reflexiones a propósito de la realidad social, la tradición jurídica y la moral cristiana en el matrimonio romano (I)», cit., pág. 3. Sobre el contenido de la patria potestad y sus límites, RIVIER, Précis du Droit de famille romain, cit., págs. 49 ss. y págs. 77 ss.; KARLOWA, O., Römische Rechtsgeschichte, II, Leipzig, I90I, págs. 79-92; VON CZYHLARZ, K.R., Lehrbuch der Institutionen des Römischen Rechtes, Prag, Wien, Leipzig, I902, págs. 269-27I; MITTEIS, L., Römisches Privatrecht bis auf die Ziet Diokletians, I, Leipzig, I908 (reimpresión Aalen, I994), págs. 72 ss.; GARDNer, Being a Roman Citizen, cit., págs. 52 ss.; PEROZZI, S., Istituzioni di Diritto romano, I, Roma, I928, $2^{a}$ edición, págs. 42I ss.; CoRnIL, Droit Romain, cit., págs. 20 ss.; CosTA, Storia del diritto romano privato dalle origini alle compilazioni giustinianee, cit., págs. 7I ss.; CollinET Giffard, Précis de Droit Romain, I, cit., págs. I74 ss.; ARCHI, L'«Epitome Gai», cit., págs. I29 ss.; Delaffon, P., Droit d'Exposition à Rome, Montpellier, I942, passim; LANFRANCHI, F., «Ius exponendi' e obbligo alimentare nel Diritto romano-classico», en Studia et Documenta Historiae et Iuris, 6, I940, págs. 5 ss.; idem, «Prospettive vecchie e nuove in tema di filiazione», cit., págs. 742 ss.; PARIBENI, La famiglia romana, cit., págs. 30 ss.; FerRini, C., Manuel di Pandette, Milano, I953, 4a edición, págs. 673 ss.; VOLTERRA, E., «Il preteso tribunale domestico in Diritto romano», en Rivista Italiana per le Scienze Giuridiche, 2, I948, págs. IO3 ss.; WATSON, A., The Law of persons in the Later Roman Republic, Oxford, I967, págs. 77 ss.; SIBER, H., Römisches Recht, II, $2^{a}$ edición, Darmstadt, I968, págs. 48 ss.; ALBANESE, Le persone nel Diritto privato romano, cit., págs. 248 ss.; LOnGo, G., su voz «patria potestà (Diritto romano)», en Novissimo Digesto Italiano, XII, Torino, I965, pág. 576; Gioffredi, G., «Funzione e limiti della patria potestas», en Nuovi Studi di Diritto greco e romano, I980, págs. 77 ss.; ARANGio-RUiZ, A.- GuARINo, A.- Pugliese, G., Il Diritto romano, Roma, I980, págs. 200-20I; MORDECHAI RABELLO, Effetti personali della "patria potestas», cit., págs. I Ss. y págs. 5I Ss., entre otras; LoBRANO, Pater et filius eadem persona -Per lo studio della patria potestas-, I, cit., págs. I46 ss.; SAlmon, P., La limitation des naissances dans la société romaine, Bruxelles, I999, págs. 80 ss; J.M. AlBURQUERQUE, «Deber legal u obligación moral originaria: generalidades introductorias sobre la prestación de alimentos en Derecho romano (I)», en R.G.D.R. (www.iustel.com), $\mathrm{n}^{\circ} 3,2004$, pp. I-I4 y la amplia bibliografía por él citada.

Redur 4 / 2006 
No obstante, como indica AlburQuerque, estos amplios poderes fueron con tiempo atenuados y/o eliminados gracias a una evolución de la concepción patriarcalista de la familia que consideraba la función del pater más como un deber que como un derecho ${ }^{\mathrm{I}}$, principio que, en buena medida, ha llegado hasta nuestro sistema jurídico a través del artículo I54 del Código Civil en el que se dispone que «la patria potestad se ejercerá siempre en beneficio de los hijos, de acuerdo con su personalidad», permitiendo corregirles de manera razonada y moderada.

Ya en Roma, sintetiza Fayer, tras las sucesivas intervenciones imperiales limitativas siempre de su aplicación, la patria potestas acabó presentándose como una domestica emendatio, una privata animadversio, es decir, «una moderada corrección doméstica, fundada en el afecto y limitada por la ley», tal y como se constata en una constitución de Valentiniano y Valente del año 365 d. C.:

C. Theod. 9.I3.I (Impp.Valentiniaunus et Valens AA. Ad Senatum): In corrigendis minoribus pro qualitate delicti senioribus propinquis tribuimus potestatem, ut, quos ad vitae decora domesticae laudis exempla non provocant, saltem correctionis medicina compellat. Neque nos in puniendis morum vitiis potestatem in immensum extendi volumus, sed iure patrio auctoritas corrigat propinqui iuvenis erratum, et privata animadversione compescat. Quodsi atrocitas facti ius domesticae emendationis excedit, placet, enormis delicti reos dedi iudicum notionit ${ }^{14}$.

Esta humanización se observa, entre otros, en la desparición del ius vitae ac necis ${ }^{15}$ que, como afirma Dalla, aunque en teoría se podría considerar vigente en época de

I3 J. Alburquerque, «Patria potestas in pietate debet, non atrocitate consistere», en Iuris Tantum, no I6, México, 2006, pp. I-20. Al respecto, vid., del mismo autor, «Deber legal u obligación moral originaria: generalidades introductorias sobre la prestación de alimentos en Derecho romano (I)», cit., pág.. 2 y pág. 5; idem, «Alimentos entre parientes: alimenta et rictus. Puntualizaciones breves sobre la transacción y la prestación en el marco de los posibles procedimientos (expedientes) de jurisdicción voluntaria», en R.G.D.R. (www.iustel.com), $\mathrm{n}^{\circ}$ 4, 2005, págs.I-2I; idem, «Alimentos entre parientes: notas, conjeturas e indicios previos a la regulación de Antonio Pio y Marco Aurelio», en R.G.D.R. (www.iustel.com), $\mathrm{n}^{\circ}$ 6, 2006, en los que efectúa un brillante estudio respecto a la influencia que los cambios en la estructura familiar romana tienen sobre la prestación de alimientos entre paritentes.

${ }^{\mathrm{I} 4}$ Breviario 9.IO.I = C. I. 9.I5.I. FAYER, La familia romana, cit., pág. 288. Al respecto, RoBERTI, M., «'Patria potestas' e 'Paterna pietas'», en Studi Albertoni, I, I935, págs. 257 ss.; FALCHI, F., Diritto penale romano I, $2^{\text {a }}$ edición, Padova, I937, págs. 42-45; SARGENTI, M., Il Diritto privato nella legislazione di Costantino, Milano, I938, págs. 86 ss.; BONFANTE, Corso di Diritto romano, Volume primo, cit., pág. IO8; FERNÁNDEZ DE BUJÁN, El filiusfamilias independiente en Roma y en el Derecho español, cit., págs. 23-24; idem, «Reflexiones a propósito de la realidad social, la tradición jurídica y la moral cristiana en el matrimonio romano (I)», cit., pág. 3; DALLA, D., «Aspetti della patria potestà e dei rapporti tra genitori e figli nell'epoca postclassica», en Atti dell'Accademia Romanistica Costantiniana, VIII Convegno Internazionale, I988, págs. 89-Io9; idem, Ricerche di Diritto delle persone, Torino, I995, págs. 7 Ss.

${ }^{15}$ Asimismo, puede observarse como señala PERIÑÁN GÓMEZ, B., «La desaparición del régimen noxal para los hijos de familia», en AA.VV., Le monde antique et les Droits de l'Homme (Actes de la $50^{e}$ Session de la Société internationale Fernad de Visscher pour l'histoire de Droits de l'antiquitè, Bruxelles, I6-I9 septembre I996), Bruxelles, I998, págs. 47 ss., en la desaparición del régimen noxal. Y en el resurgimiento del ius vendendi respecto a los neonatos, siendo reconocido y regulado por Constantino y los emperadores posteriores, motivados por la influencia cristiana ante la necesidad de salvar el mayor número de vidas humanas frente a la extrema pobreza de algunos estratos sociales. En consecuencia, su readmisión no fue debida al deseo de recuperar las atribuciones del paterfamilias sino, en opinión de BIONDI, B., Il diritto romano cristiano III, Milano, I954, págs. I9 ss., a su consideración como un mal menor respecto a la exposición o al homicidio. C. Theod. 5.IO.I= C. I. 4.43.2; II-27.I y 2; 3.3.I; Novellae Valentiniani, 33(32), entre otras. Sobre el ius

Redur 4 / 2006 
Constantino $^{\mathrm{I} 6}$, las continuas limitaciones a su ejercicio, sustituyendo la autoridad pública a la paterna en las puniciones graves y la reprobación de la conciencia social unida a la influencia del cristianismo, lo habían vaciado práticamente de contenido y, en todo caso, concluye el autor, la no existencia de tal derecho puede testimoniarse mediante una constitución del año 374 d. C., en la que Valentino, Valente y Graciano sancionaron el infanticidio con la pena de la Lex Cornelia de sicariis.

C. Theod. 9.I4.I (Imppp. Valentinuanus, Valens et Gratianus AAA. ad Probum P.P.)=: $S i$ quis necandi infantis piaculum aggressus aggressave sit, sciat, se capitali supplicio esse puniendum ${ }^{\mathrm{I}}$.

vendendi en el Bajo Imperio, entre otros, RIVIER, Précis du Droit de famille romain, cit., pág. 79; BONFANTE, P., «Il 'ius vendendi' del 'paterfamilias' e la legge 2 COD. 4, 43 di Costantino», en Studi in onore di Fadda, I, I906, págs. II5-I20; idem, Corso di Diritto romano, Volume primo, cit., págs. IO9-IIo y págs. II2-II6; FALCHI, Diritto penale romano I, cit., págs. 42-43; SARGENTI, Il Diritto privato nella legislazione di Costantino, cit., págs. 27 ss.; VOLTERRA, E., «L'efficacia delle costituzioni imperiali emanate per le province e l'istituto dell'expositio», en Studi in onore di E. Besta, I, I939, págs. 469 ss.; PARABENI, La famiglia romana, cit., pág. 33; LONGO, su voz «patria potestà (Diritto romano)», cit., pág. 576; CAPOGROSSI COLOGNESI, su voz «patria potestà (Diritto romano)», cit., págs. 244 Ss.; AlBANESE, Le persone nel Diritto privato romano, cit., págs. 252 ss.; FosSATI VANZETTI, M.B., «Vendita ed esposizione degli infanti da Costantino a Giustiniano», en Studia et Documenta Historiae et Iuris, XLIX, I983, págs. I79-224; BIANCHINI, M., «Provvidenze costantiniane a favore di genitori indigenti: per una lettura di CTh. II.27.I-2», en Annali Genova, 20, I984-I985, págs. 2348; EVAnS-GRuBBS, J., «Munita coniugia». The Emperor Constantine's legislation on marriage and the family, Universidad de Stanford, I987, págs. I87-202; MARTINI, R., «Sulla vendita dei neonati nella legislazione costantiniana», en Atti dell'Accademia Romanistica Costantiniana, VII Convegno Internazionale, Perugia, I988, págs. 423-433; DALLA, «Aspetti della patria potestà e dei rapporti tra genitori e figli nell'epoca postclassica», cit., págs. 94 ss.; idem, Ricerche di Diritto delle persone, cit., págs. 9 ss.; FAYER, La familia romana, cit., págs. 203 ss. y pág. 289; SALMON, La limitation des naissances dans la société romaine, cit., pág. 8I n. I3.

${ }^{\text {I6 }}$ En el año 3ig d. C., Constantino estableció que el padre que matara al hijo sería declarado culpable de parricidio (C. Theod. 9.I5.I= C.I. 9.I7.I), si mediaba dolo malo (Institutae Iustiniani, 4.I8.6). No obstante, en una constitución del 323 (C. Theod. 4.8.6) se recuerda la institución como vigente y Justinano, al incorporar esta constitución al Código sustituye el «permissa est» por «olim, erat permissa» (C. I. 8.46.Io), aclarando cómo en un tiempo anterior la misma estuvo permitida. Esto, afirma DALLA, «Aspetti della patria potestà e dei rapporti tra genitori e figli nell'epoca postclassica», cit., págs. 89-109, idem, Ricerche di Diritto delle persone, cit., págs. I ss., podría suponer que «norme criminale e regola antica potrebbero, in teoria, coesistere». Al respecto, REIN, W., Das Kriminalrecht der Römer von Romulus bis auf Justinian, Leipzig, I844 (reimpresión Aalen, I962), págs. 440 ss.; FALCHI, Diritto penale romano I, cit., págs. 42-45; SARGENTI, Il Diritto privato nella legislazione di Costantino, cit., págs. 86 ss.; BonfANTE, Corso di Diritto romano, Volume primo, cit., págs. I07 ss.

${ }^{I 7}$ Breviario, 9.II.I= C. I. 9.I6.8. DALLA, «Aspetti della patria potestà e dei rapporti tra genitori e figli nell'epoca postclassica», cit., pág. 92; idem, Ricerche di Diritto delle persone, cit., págs. 7 ss., que se pregunta si este derecho podría ejercerse contra los nacidos deformes, habida cuenta de que Justiniano recoge en el Digesto el pasaje de Paulo que afirmaba que no se podía llamar hijos a los nacidos con grave deformidad (D. I.5.I4). Sobre este derecho a partir del Bajo Imperio, REIN, Das Kriminalrecht der Römer von Romulus bis auf Justinian, cit., págs. 440 ss.; SARGENTI, Il Diritto privato nella legislazione di Costantino, cit., págs. 86 ss.; LONGO, su voz «patria potestà (Diritto romano)», cit., pág. 576; BonfANTE, Corso di Diritto romano, Volume primo, cit., págs. I07-Io8 y págs. III-II2; AlbANESE, Le persone nel Diritto privato romano, cit., págs. 249 sS.; CAPOGROSSI COlOGNESI, su voz «patria potestà (Diritto romano)», cit., págs. 242 ss.; FERNÁNDEZ DE BUJÁN, El filiusfamilias independiente en Roma y en el Derecho español, cit., pág. 23; FAYER, La familia romana, cit., págs. I73 ss. y pág. 288; SALMON, La limitation des naissances dans la société romaine, cit., pág. 8I. 
A esta progresiva dulcificación de los poderes inherentes a la patria potestas contribuyeron ineludiblemente una serie de factores que comienzan a producirse desde finales del período republicano o principios del Imperio y que terminan por consolidarse en las épocas sucesivas, especialmente, el tránsito de la familia agnaticia a la cognaticia basada en vínculos de sangre ${ }^{\text {I8 }}$ y la mayor capacidad patrimonial de los alieni iuris a través de los peculios $^{\mathrm{I} 9}$.

Por otro lado, es obligatorio recordar con AGUDo RUIz el denominado proceso de emancipación femenina, gracias al cual las mujeres fueron adquiendo una mayor capacidad jurídica y una mayor capacidad de obrar ${ }^{2 \circ}$. Ciertamente esta evolución experimentó un

I8 Así por ejemplo, la lex Cinia de donis et muneribus, del año 204 a. C., permitió las donaciones a sobrinos o sobrinas (Cicerón, De oratore, 2.71.286). Asimismo la Lex Furia testamentari prohibió hacer legados superiores a Iooo ases, salvo cuando se tratase, entre otras personas, de parientes cognados entre el sexto y el séptimo grado. A este respecto, GARCÍA GARRIDO, M., Ivs vxorivm. El régimen patrimonial de la mujer casada, Madrid, I958, págs. 79 ss.; CASAVOLA, F., Lex Cinia. Contributo alla storia delle origini della donazione romana, Napoli, I96o, passim; Astolfi, Il matrimonio nel diritto romano preclassico, Verona, 200o, pág. 39; AlBURQUERQUE, «Deber legal u obligación moral originaria: generalidades introductorias sobre la prestación de alimentos en Derecho romano (I)», cit., p. 2; FERNÁNDEZ DE BUJÁN, «Reflexiones a propósito de la realidad social, la tradición jurídica y la moral cristiana en el matrimonio romano (I)», cit., pág. 3.

${ }^{\text {I9 }}$ Rivier, Précis du Droit de famille romain, cit., pág. 84; PARIBENI, La famiglia romana, cit., pág. 32; LA Rosa, F., I peculi speciali in Diritto romano, Milano, I963, págs. 5 ss.; GARCÍA GARRIDO, Ivs vXorivm. El régimen patrimonial de la mujer casada en el derecho romano, cit., págs. 5 SS.; BURDESE, A., su voz «capacità (Diritto romano)», en Enciclopedia del Diritto, VI, Milano, I96o, págs. I-3; Bonfante, Corso di Diritto romano, Volume primo, cit., pág. iı9; FusTEL DE Coulanges, La ciudad antigua. Estudio sobre el Culto, el Derecho y las Instituciones de Grecia y Roma, cit., pág. 63; AlbANESE, Le persone nel Diritto privato romano, cit., pág. 2II, pág. 213, págs. 246-247 y págs. 27I SS.; FERNÁNDEZ DE BUJÁn, El filiusfamilias independiente en Roma y en el Derecho español, cit., págs. 24 ss.; WACKE, A., «Le pécule: patrimoine du père ou propiété du fils? Le destin du pécule après la fin de la puissance domestique», en Estudios de Derecho romano y moderno en cuatro idiomas, Madrid, I996, pág. I63; HeRnANZ PILAR, J., El ivssum en las relaciones potestativas, Valladolid, I993, págs. I5 SS., págs. 33 ss., págs. 45 ss., págs. 65 ss., págs. 87 ss. y págs. I37 Ss.; FAYER, La familia romana, cit., pág. 73 y págs. 250 ss.; PERIÑÁn GóMEZ, Antecedentes y consecuencias del SC. Macedoniano, cit., pág. 95; Alburquerque, «Deber legal u obligación moral originaria: generalidades introductorias sobre la prestación de alimentos en Derecho romano (I)», cit., p. 2.

${ }^{\circ}$ Agudo Ruiz, A., Abogacía y abogados. Un estudio histórico-jurídico, Logroño-Zaragoza, I997, págs. 2 I2 Ss., en el que señala cómo este proceso de emancipación no pudo vencer determinadas limitaciones sociales como la reserva del ejercicio de la abogacía a los varones (D. 3.I.I』5; D. 50.I7.2 pr; C.I. 2.I3[I2].4; C.I. 2.I3[I2].I8; C.I. 2.I3[I2]2I; C.I. 8.3.2). No obstante la adquisición de una mayor capacidad jurídica y de obrar se desprende por ejemplo, de la lex Oppia (a. 2I5 a. C. derogada en el I95 a. C.), que les prohibió ponerse joyas en exceso y vestidos coloridos y de la lex Voconia (a. I69 a. C.) que habría prohibido que las mujeres, excepto las vestales y la Flaminica Dialis, pudiesen recibir una herencia de un ciudadano romano censado en la primera clase y que, en general, que no pudiesen heredar un patrimonio superior a 100.000 ases. Asimismo del surgimiento de las cautiones rei uxoriae y de la actio rei uxoria para recuperar la dote en caso de divoricio. Además, desde finales de la República, las mujeres buscaron subterfugios para eludir su incapacidad como prueba la coemptio fiduciae tutelae, a través de la cual se sometían a la tutela de un hombre de su confianza, o la coemptio fiduciaria testamenti faciendi gratia, que les brindaba la posibilidad de hacer testamento y a través de los pretores podían obtener la posesión de los bienes hereditarios. Al respecto, DEVILLA, Il carattere della famiglia ed il regime patrimoniale dei coniugi, cit., págs. 324 Ss.; FöRTSCH, B., Die politische Rolle der Frau in der römischen Republik, Stuttgart, I935, passim; MARTINI, R., «'Coemptio fiduciae causa' e 'Senes coemptionales'», en Studi in onore di Arnaldo Biscardi, vol. II, I982, págs. I7I ss.; GuARINO, A., «Lex Bocona», en Labeo, 28, I982, págs. I88 ss.; idem, «'Minima de mulieribus'», en Pagine di diritto romano, vol. II, Napoli, I993, págs. 35I ss.; Culham, P.H., «The Lex Oppia», en Latomus, 4I, I982, págs. 787 ss.; SiRAGO, V.A., Feminismo a Roma nel Primo Imperio, Roma, I983, págs. 3I ss., págs. I03 Ss. y págs. I23 Ss.; PEPPE, L., Posizione giuridica e ruolo sociale della donna romana in età repubblicana, Milano, I984, págs. 26 ss., págs. 42 ss. y págs. $5^{2}$ ss., entre otras; CiCCOTTI, E., Donne e politica negli ultimi anni della

Redur 4 / 2006 
retroceso con el reconocimiento del cristianismo como religion oficial del Imperio en el siglo IV d. C. (al entender que la esposa estaba subordinada al marido), pero consiguió conservar latente una de sus determinantes causas y/o efectos acaecida siglos atrás: el declive de la conventio in manum a partir del siglo III a. C. y, particularmente, desde el siglo I a. $\mathrm{C}^{2 \mathrm{I}}$.

\section{Diferencia entre matrimonium y conventio in manum.}

Esta circunstancia del incremento de los matrimonios «libres» nos permite conectar con el último y más complejo concepto objeto de reflexión en este trabajo: aquél de materfamilias.

En realidad, ha sido un error reduccionista muy frecuente en la doctrina, la afirmación de que en el Derecho romano existieron dos tipos de matrimonio:

a) Un matrimonio cum manu, -celebrado mediante un rito religioso (confarreatio), una compra simulada (coemptio matrimonii causa) o una cohabitación anual initerrumpida $\left(\right.$ usus $^{22}-$, en virtud del cual la esposa pasaba a quedar

repubblica romana, Paris-Bonn, I985, passim; GORIA, F., «Il dibattito sull'abrogazione della lex Oppia e la condizione giuridica della donna romana», en Atti del convengo su «La donna nel mondo antico», a cura di $R$. Uglione, Torino, $21-23$ di I986, Torino, I987 págs. 265 ss.; CANTARELLA, E., La calamidad ambigua, trad. A. Pociña, Madrid, I99I, págs. 2 I7 ss. y págs. 239 ss.; idem, Pasado próximo. Mujeres romanas de Táctia a Sulpicia, trad. M Isabel Núñez, Madrid, I996, págs. Io7 ss. y págs. IIg ss.; BAuman, R., Women and Politics in Ancient Rome, London, I992, págs. 33 ss.; CASTREsAnA, A., Catálogo de virtudes femeninas, Madrid, I993, págs. 72 ss., págs. 80 ss. y págs. 99 ss.; FrAnCIOSI, Famiglia e persone in Roma antica. Dall'età arcaica al Principato, cit., pág. 73 y págs. 9I ss.; CROOK, J.A., «Women in roman succession», en RAWSON (Ed.), The Family in ancient Rome, cit., págs. 58 ss.; idem, «Feminine inadequacy and the 'Senatusconsultum Velleianum'», en RAWSON (Ed,), The Family in ancient Rome, cit., págs. 83 ss.; FAYER, La familia romana, cit., págs. 515-556; GARDNER, J.F., Women in Roman Law and Society, London, I995, pág. I70 ss.; ROMANO, A., Matrimonium iustum. Valori economici e valori culturali nella storia giuridica del matrimonio, Napoli, I996, págs. 85 ss.; OHNSTON, D., Roman Law in Context, Cambridge, I999, págs. 39 ss.; Astolfi, IL matrimonio nel diritto romano preclassico, cit., págs. 269 ss.; DixON, S., Reading Roman Women, London, 2001, págs. 69 ss.

${ }^{21}$ Astolfi, Il matrimonio nel diritto romano preclassico, cit., pág. 99. El incremento de los matrimonios libres a partir de finales del siglo III a. C. ha sido apuntado también, entre otros, por SIBER, Römisches Recht, II, cit., pág. 506 y pág. 508; CREMADES, I.-PARICIO, J., «Dos et virtus». Devolución de la dote y sanción a la mujer romana por sus malas costumbres, Barcelona, I983, pág. 35: CAntarella, Pasado próximo. Mujeres romanas de Tácita a Sulpicia, cit., pág. Io7. Por su parte BRINI, G., Matrimonio e divorzio nel diritto romano, Parte prima, Il matrimonio romano, reimpresión anastática, Roma, I975, págs. I35-136, considera que incluso desde la época de las XII Tablas el matrimonio sine manu «debía haber hecho bastante camino de cara a su fijación y reconocimiento en la vida», pero hasta los últimos tiempos de la República, «el matrimonio cum manu permanence como el matrimonio normal, el matrimonio, en efecto, del derecho civil o el más legítimamente romano».

${ }^{22}$ Sobre la ceremonia religiosa de la confarreatio y su ritual, mediante una especie de sacrificio que se hacía a Júpiter Fárreo en el que se presentaba un pan de trigo y se procedía al pronunciamiento de fórmulas prescritas y solemnes en presencia de diez testigos (Gayo, Institutae, I.II2), la coemptio, evolución de la primitiva mancipatium matrimonii causa que consistía en una imaginaria venditio (Gayo, Institutae, I.II3) y el usus o convivencia initerrumpida durante un año, cuyos efectos podían ser evitados si la esposa se ausentaba durante tres noches al año del domicilio conyugal (Gayo, Institutae, I.III), vid., por todos, PEROZZI, S., «'Confarreatio' e 'coemptio matrimonii causa'», en Scritti giuridici, III, Milano, I948, págs. 528 ss.; CANTARELLA, E., «Sui rapporti fra 
sometida a la potestad del marido (manus), si éste era sui iuris, o de su paterfamilias, si era alieni iuris, y

b) Un matrimonio sine manu en virtud del cual la esposa continuaba bajo la potestas de su propio paterfamilias o, incluso, ser sui iuris si no estaba sometida a patria postestas ajena ${ }^{23}$.

Empero, tras los estudios efectuados por Volterra ${ }^{24}$, es cada vez más numerosa la posición doctrinal que postula una concepción unitaria del matrimonio como instituto

matrimonio e 'conventio in manum'», en Rivista Italiana per la Scienze Giuridiche, III (Io), I959I962, págs. I8I ss.; idem, «' $L$ usus' e la 'conventio in manum'», en Labeo, 4I, I995, págs. 434 ss.; BENEDEK, F., Die Conventio in Manum und die Förmlichkeiten der Eheschlessung im römischen Recht, Pécs, I978, págs. 9 ss.; BIONDI, B., «'Farreo, coemptione, usu’», en Sodalitas in onore di Guarino, vol. III, Napoli, I984, págs. I302 ss.; TREGGIARI, S., Roman marriage. Iusti Coniuges from the Time of Cicero to the Time of Ulpian, Oxford, I993, págs. I6 ss.; PIRO, I., «Usl» in manum comvenire, Napoli, I994, passim; NiCosia, G., Silloge. Scritti 1965-1996, vol. II, Catania, I998, págs. 7I7 SS.; FERNÁNDEZ DE BUJÁN, «Reflexiones a propósito de la realidad social, la tradición jurídica y la moral cristiana en el matrimonio romano (I)», cit., pág. 3.

${ }^{23}$ Entre ellos, aunque con distintas posturas sobre el momento en que tal distinción surgió, VoN WÄCHTER, K.G., Über Ehescheidungen bei den Römern, Stuttgart, I822 (reimpresión Aalen, I998), págs. 28 ss.; ROßBACH, A., Untersuchungen über die römische Ehe, Stuttgart, I853, págs. 8 ss.; Devilla, Il carattere della famiglia ed il regime patrimoniale dei coniugi, Parte Prima, cit., págs. 2II ss.; BRINI, Matrimonio e divorzio nel diritto romano, Parte prima, Il matrimonio romano, cit, págs. 37-4I y págs. 48-58, entre otras; MANENTI, C., Della inoponibilità delle condizioni ai negozi giuridici, ed in specie delle condizioni apposte al matrimonio, Siena, I889, págs. 40 ss.; RIVIER Précis du Droit de famille romain, cit., págs. III ss., págs. I6ı ss. y págs. I75 ss., entre otras; WeSTRUP, C.W., Quelques observations sur les origines du mariage par «usus» et du mariage sans "manus», dans l'ancien droit romain, Paris, 1926, págs. I ss.; idem, Recherches sur les formes antiques de mariage dans l'ancien droit romain, København, I943, págs. 3I ss. y págs. 80-8I, entre otras; Collinet - Giffard, Précis de Droit Romain, I, cit., págs. 205 ss.; BozZA, F., «Manus e matrimonio», en Annali della Università di Macerata, vol. XV, I942, págs. III ss.; GARCía GARRIDO, «Conventio in manum y matrimonio», en Varia Romana, Anuario de Historia de Derecho Español, I956, pp. 78I ss.; idem, «La convivencia en la concepción romana del matrimonio» en AA.VV., Libro homenaje a Giménez Fernández, vol. II, Sevilla, I967, pp. 637 ss.; SIBER, Römisches Recht, II, cit., págs. 504-506; WATSON, The Law of person in the Later Roman Republic, cit., págs. 23 ss.; idem, The Spirit of Roman Law, I995, pág. 9; GUIFFRÈ, V., Il diritto dei privati nell'esperienza romana. I principali gangli, Napoli, I993, pág. 333; ARANGIO-RUIZ, V., Istituzioni di diritto romano, Napoli, I994, págs. 434 ss.; VoCI, P., Istituzioni di diritto romano, Milano, I996, pág. 5I7; DuCos, Roma e il diritto, cit., págs. 52 ss.; ARGÜELlo, L.R., Manual de Derecho romano. Historia e Instituciones, Buenos Aires, I998, págs. 425 ss.; ARENDS OLSEN, La femme et l'enfant dans les unions illégitimes à Rome. L'évolution du droit jusqu'au début de l'Empire, cit., págs. I5 ss.; DE MARTino, F., Individualismo e diritto romano privato, Torino, I999, pág. I5; FERNÁNDEZ DE BUJÁN, «Reflexiones a propósito de la realidad social, la tradición jurídica y la moral cristiana en el matrimonio romano (I)», cit., págs. 2 ss, quien, a nuestro juicio, utiliza la terminología clásica de distinguir dos tipos de matrimonio sólo desde un punto de vista metodológico ya que en su n. 26, respecto al análisis de la relación entre matrimonium y conventio in manum, se remite exclusivamente a Volterra, autor que, como veremos infra, defiende la distinción entre ambos institutos. Vid., asimismo, las recientes traducciones de las obras de VON IHERING, R., El Espíritu del Derecho romano, (abreviatura por F. Vela), Madrid, I997, pág. I54 y Schulz, F., Principios del Derecho romano, trad. por M. Abellán Velasco, Madrid, 2000, pág. 2I4.

${ }^{24}$ VolterRA, E., La conception du mariage d'aprés les juristes romains, Padua, I940, págs. 2 ss. (Síntesis en Scritti giuridici, vol. II, Napoli-Paris, I99I-I992, págs. 3 ss.); idem, «Ancora sulla manus e sul matrimonio», en Studi Solazzi, Milano, I948, págs. 675-688 (= Scritti giuridici, vol. II, cit., págs. 83 ss.); idem, «Nuove osservazioni sulla conventio in manum», en Atti del Congresso Internazionale di Diritto romano di Verona, vol. III, Milano, I95I, págs. 27-45 (= Scritti giuridici, vol. II, cit., págs. 199 ss.); idem, «La conception du mariage à Rome», en Revue International des Droit de l'Antiquité, 2, I955, págs. 365-379; idem, «Nuove ricerche sulla conventio in manum», Atti

Redur 4 / 2006 
diferente, aunque coetáneo, a la conventio in manum ${ }^{25}$. La estrecha relación de ambos institutos a lo largo de la Monarquía y de los primeros siglos de la República, como consecuencia del protagonismo que en este período histórico adquirieron las relaciones agnaticias, no debe conducir a su identificación puesto que a pesar de que ambos se dieron simultáneamente, como explica Volterra, mientras el matrimonio atribuía a la mujer el estado de esposa (uxor), la manus regulaba su posición jurídica en el grupo agnaticiofamiliar del esposo como filia loco de éste o de su paterfamilias ${ }^{26}$.

Según el autor, la regulación del usus recogida, conforme al testimonio de Gayo, en las XII Tablas, es clarificadora a este respecto. En función de la misma, aunque el matrimonio se celebrase sine manu, el marido adquiría la manus sobre su mujer si ésta

dell'Accadamia nazarina dei Lincei, I966, II, págs. 25I-355 (= Scritti giuridici, vol. III, Napoli-Paris, I99I-I992, págs. 3 Ss.); idem, «La conventio in manum e il matrimonio romano», en Rivista Italiana per la Scienze Giuridica, I2, I968, págs. 205 ss. (= Scritti giuridici, vol. III, cit., págs. I55 ss.); idem, su voz, «matrimonio (diritto romano)», en Enciclopedia del Diritto, vol. XXV, Milano, I975, págs. 726 ss. En el mismo sentido ya se habían pronunciado con anterioridad, Di MARZo, S., Lezioni sul matrimonio romano, Palermo, I9I9, pág. 62 (= Roma, I972, págs. 62 ss., edición utilizada por nosotros); Bonfante, P., Corso di Diritto romano, en su primera edición de Milano, i995 (= Corso di Diritto romano, Volume primo, cit., pág. 262).

${ }^{25}$ Entre otros, ORESTANO, R., La struttura giuridica del matrimonio romano. Dal diritto classico al diritto giustinianeo, Milano, I95I págs. I4 ss.; DANIELI, R., «'Manus' e 'conventio in manum’», en Studi Urbinati, I9, I950-I95I, pág. I77 n. 26; LAURIA, M., Matrimonio-Dote in Diritto romano, Napoli, I952, pág. 3; DelPINI, F., Divorzio e separazione dei coniugi nel diritto romano e nella dottrina della chiesa fino al secolo $V$, Torino, I956, págs. 26-28; Olís RoBLEDA, S.J., El matrimonio en Derecho romano. Esencia, requisitos de validez, efectos, disolubilidad, Roma, I970, págs. I ss. y págs. $25 \mathrm{ss}$, con un profundo estudio de ambas posturas; DAZA MARTínEZ, J., «'Nuptiae' et 'matrimonium'», en AA.VV., Estudios jurídicos en homenaje al profesor Ursicino Álvarez Suárez, Madrid, I978, pág. 57; Huber, J., Der Ehekonsens im römischen Recht, Roma, I977 pág. I2I; VÁZQUEZ DE MARCoS, J., El divorcio en Roma y en España, Madrid, I98I, pág. 7; FERNÁNDEZ BAQUERO, M.E., Repudium-Divortium. (Origen y configuración jurídica hasta la legislación matrimonial de Augusto), Granada, I988, págs. 30 ss. y págs. 55 ss.; idem, «Conubium y sponsalia: reflexiones sobre la concepción originaria del matrimonio romano», cit., pág. I99; NÚÑEZ PAZ, M.I., Consentimiento matrimonial y divorcio en Roma, Salamanca, I988, págs. I9 ss.; TALAMACA, M., Istituzioni di Diritto romano, Milano, I990, págs. I32; PUGliese, G., Istituzioni di Diritto romano, Torino, I99I, págs. I02-I03; ROMANO, Matrimonium iustum. Valori economici e valori culturali nella storia giuridica del matrimonio, cit., págs. I6 ss.; SERRANO, F., Diritto privato, economia e società nella storia di Roma, Prima parte, Napoli, I999, pág. I65 y pág. I88; IGLESIAS, J., Derecho romano, I2 $2^{a}$ edición, Barcelona, I999, pág. 340; MARTINI, R., Appunti di Diritto romano privato, Milano, 2000, págs. 33 ss.; D’AMICO, P., Diritto privato romano comparato con il moderno, cit., pág. 240 y págs. 247 SS.; EISENRING, G., Die römischen Ehe als Rechtsverhältnis, Wien-Köln-Weimar, 2002, págs. IO ss.

${ }^{26}$ VOLTERrA, La conception du mariage d'aprés les juristes romains, cit., págs. 96 ss. Que la importancia de la familia agnaticia en la vida política y social de los primeros siglos de Roma comportase que el matrimonio fuese generalmente acompañado de la conventio in manum ha sido admitido, entre otros, por LÓPEZ ROSA, «Familia y matrimonio: A propósito de la organización social y política en la Roma antigua», cit., pág. 420; DELPINI, Divorzio e separazione dei coniugi nel diritto romano e nella dottrina della chiesa fino al secolo $V$, cit., págs. 26-28; GAUDEMET, J., Les communautés familiales, Paris, I963, pág. 57; NúÑEZ PAZ, Consentimiento matrimonial y divorcio en Roma, cit., págs. 22 ss.; TALAMACA, Istituzioni di Diritto romano, cit., pág. I32; PUGLIESE, Istituzioni di Diritto romano, cit., págs. IO2-IO3; FRANCIOSI, G., Clan gentilizio e struttura monogamiche. Contributo alla storia della famiglia romana, Napoli, I999, pág. 89 y pág. I47; FAYER, La familia romana, cit., pág. 20; SERRAO, Diritto privato, economia e società nella storia di Roma, cit., pág. I85. Cfr. RASI, P., Consensus facit nuptias, Milano, I946, págs. 5 ss., para quien primero surgió la conventio y después el matrimonio, considerando que no podía existir un matrimonio con la conventio porque ambos institutos se excluían el uno al otro.

Redur 4 / 2006 
residía en el domicilio del esposo un año ininterrumpido, efecto que la esposa podía eludir ausentándose tres noches consecutivas del mismo (trinoctium):

GAYO, Institutae, I.III: Usu in manum conueniebat quae anno continuo nupta perseuerabat; quia enim uelut annua possessione usu capiebatur, in familiam uiri transibat filiaeque locum optinebat. Itaque lege XII tabularum cautum est, ut si qua nollet eo modo in manum mariti conuenire, ea quotannis trinoctio abesset atque eo modo (usum) cuiusque anni interrumperet. Sed hoc totum ius partim legibus sublatum est, partim ipsa desuetudine obliteratum est ${ }^{27}$.

De esta norma decenviral se desprende que tanto la forma de constitución de la manus (usus) como la forma de evitarla (trinoctium) en ella previstas se apoyan sobre el presupuesto de la sociedad conyugal en el domicilio marital por efecto del matrimonio el cual, conforme a la acertada opinión de Volterra, debía existir como requisito previo para la adquisición de dicha potestad, circunstancia que pone de manifiesto sin nigún género de dudas que se trataba de dos institutos diferentes, con efectos distintos, que podían celebrarse de manera no coetánea o, incluso, no coexistir en el núcleo conyugal, aunque, como hemos visto supra, hasta avanzada la República la tendencia fue la contraria, de ahí el error de su identificación ${ }^{28}$.

\section{Análisis de los diversos significados del concepto materfamilias.}

La presencia o no de la conventio in manum en la celebración del matrimonio comportaba, en consecuencia, un mayor o menor grado de integración de la uxor en la familia agnaticia del marido, lo que ha conducido a algunos autores a limitar el calificativo de materfamilias a la uxor cum manu.

${ }^{27}$ VOLTERRA, «Ancora sulla manus e sul matrimonio», cit., pág. 677.

${ }^{28}$ VOLTERRA, «La conception du mariage à Rome», cit., pág. 369; idem, «Ancora sulla manus e sul matrimonio», cit., pág. 682; idem, «Nuove osservazioni sulla 'conventium in manum'», cit., pág. 30. En el mismo sentido, Bonfante, Corso di Diritto romano, Volume primo, cit., pág. 57; RoBlEDA, El matrimonio en Derecho romano. Esencia, requisitos de validez, efectos, disolubilidad, cit., págs. 30 ss.; FERNÁNDEZ BAQUERO, Repudium-Divortium. (Origen y configuración jurídica hasta la legislación matrimonial de Augusto), cit., págs. 296 ss.; NÚÑEZ PAZ, Consentimiento matrimonial y divorcio en Roma, cit., pág. 88 y pág. 92; FrANCIOSI, Famiglia e persone in Roma antica. Dall'età arcaica al Principato, cit., pág. I37 y pág. I4I; RomAno, Matrimonium iustum. Valori economici e valori culturali nella storia giuridica del matrimonio, cit., pág. 69; SERRAO, Diritto privato, economia e società nella storia di Roma, cit., pág. I88; ASTOLFI, Il matrimonio nel diritto romano preclassico, cit., pág. I08, pág. I98 y pág. 206; MARTINI, Appunti di Diritto romano privato, cit., pág. 34; D’ALMICO, Diritto privato romano comparato con il moderno, cit., pág. 247; PANERo GUTIÉRREZ, R., Derecho romano, Valencia, 2000, pág. 299, consideran que la exitencia anual de un matrimonio válido es un requisito para el usus. Cfr., entre otros, KARLOWA, Römische Rechtsgeschichte, II, cit., págs. I6I ss.; MITTEIS, Römisches Privatrecht I, cit., pág. 25I; PARIBENI, La famiglia romana, cit., pág. 37; Grimal, P., El amor en la Roma antigua, trad. J. Palacio, Barcelona, I999, pág. 84; ARENDS OLSEN, La femme et l'enfant dans les unions illégitimes à Rome. L'évolution du droit jusqu'au debut de l'Empire, cit., pág. I6, para quienes hasta transcurrido el año no existiría matrimonio legítimo.

Por su parte WeSTRUP, Quelques observations sur les origines deu mariage par «usus» et du mariage sans «manus» dans l'ancien droit romain, cit., págs. 6 ss.; idem, Recherches sur les formes antiques de mariage dans l'ancien droit romain, cit., págs. 34 ss., defiende la exisitencia de dos tipos de usus. uno concebido como una unión pública, exclusiva y duradera matrimonii causa pero sin manus tolerada por el ordenamiento y que fue reconocido como matrimonio justum por las XII Tablas; y otro como un modo reconocido en el derecho plebeyo de constituir la conventio in manum y que presupone la existencia de un matrimonio legítimo.

Redur 4 / 2006 
En este sentido, afirma Astolfi, «si el matrimonio no iba acompañado de la manus, la convivencia se reducía a la participación en el culto a los Lares y fuego sagrado y en el sometimiento de la mujer a la potestad disciplinaria del marido para garantizar la procreación legítima. En cambio, si el matrimonio iba acompañado de la constitución de la manus, la esposa participaba también en el culto de los dioses Manes, los antepasados muertos del esposo, dado que la conventio in manum extinguía la relación agnaticia que ligaba a la mujer con los componente vivos y difuntos de la familia paterna creando una nueva relación con los componentes vivos y difuntos de la familia de su marido, que junto a la participación de los sacra provocaba la adquisición de la condición de filia loco del marido, el aumento de sus poderes disciplinarios hasta ostentar el ius vendendi sobre la esposa y en el reconocimiento del papel preeminente de ésta en la organización de la familia atribuyéndole el apelativo de materfamilias y el derecho a suceder a su esposo como heres sua» ${ }^{29}$.

A decir verdad, se puede afirmar con Brini, que en algunas fuentes el término uxor era empleado para indicar que una esposa no se encontraba in manu, mientras que con el término materfamilias se designaba a aquélla in manu conventa. Significativo a este respecto son los célebres pasajes de Cicerón y Aulo Gellio:

CICERÓN, Topica, 3.I4: «A forma generis, quam interdum, quo planius accipiatur, partem licet nominare hoc modo: Si ita Fabiae pecunia legata est a viro, si ei viro materfamilias esset; si ea in manum non convenerat, nihil debetur. Genus enim est uxor; eius duae formae: una matrumfamilias, eae sunt, quae in manum convenerunt; altera earum, quae tantum modo uxores habentur. Qua in parte cum fuerit Fabia, legatum ei non videtur».

Aulo Gellio, Noctes Atticae, i8.6.9: «...Enimvero illud impendio probabilius est, quod idonei vocum antiquarum enarratores tradiderunt, matronam dictam esse propie, quae in matrimonium cum viro convenisset, quoad in eo matrimonio maneret, etiamsi liberi nondum nati forent, dictamque ita esse a matris nomine, non adepto iam, sed cum spe et omine mox adipiscendi, unde ipsum quoque "matrimonium" dicitur, matrem autem familias appellatam esse eam solam, quae in mariti manu mancipioque aut in eius, in cuius maritus, manu

${ }^{29}$ Astolfi, Il matrimonio nel diritto romano preclassico, cit., págs. 6 ss. y págs. 94 ss. Por su parte, WESTRUP, Quelques observations sur les origines du mariage par «usus» et du mariage sans «manus» dans l'ancien droit romain, cit., págs. II-I6, pág. 23 y pág. 32 n. 3; idem, Recherches sur les formes antiques de mariage dans l'ancien droit romain, cit., págs. 38-40, pág. 43 y pág. 54, reserva el título de materfamilias a la esposa in manu y califica a la esposa sine manu como uxor o matrona, título que la legitima como esposa y madre por lo cual, pese a que es una extranjera en la casa del marido, se le reconoce una determinada situación jurídica. Asimismo, NúÑEZ PAZ, Consentimiento matrimonial y divorcio en Roma, cit., pág. 22, considera que sólo la conventio in manum dotaría al matrimonio de relevancia social, como denota el calificativo de materfamilias, reservada a la esposa in manum, única que participaría plenamente del status de su marido, mientras que la esposa sine manu sería considerada como una «mera huesped de pago en el hogar conyungal». Y en el mismo sentido se pronuncian, entre otros, ROßBACH, Untersuchungen über die römische Ehe, cit., págs. 89, págs. 273 ss. y págs. 35I ss.; HöLDER, E., Die römische Ehe, Zürich, I874, págs. I2 ss. y págs. 25 ss.; CZYHLARZ, Lehrbuch der Institutionem des Römischen Rechtes, cit., págs. 247-249 y págs. 255256; RAGE-Brocard, M., Rites de mariage. La dedvctio in domvm mariti, Paris, I934, págs. I05 ss.; BRINI, Matrimonio e divorzio nel diritto romano, Parte prima, Il matrimonio romano, cit., págs. 3746 y págs. I35-136; CosTA, Storia del diritto romano privato dalle origini alle compilazioni giustinianee, cit., págs. 9 ss.; DuPONT, F., La vita quotidiana nella Roma repubblicana, Roma-Bari, I990, pág. II5; FAYER, La familia romana, cit., pág. 20, quien reconoce un posterior significado de materfamilias como mujer casada de buena familia y de buenas costumbres; VocI, Istituzioni di diritto romano, cit., pág. 57 I.

Redur 4 / 2006 
mancipioque esset: quoniam non in matrimonium tantum, sed in familiam quoque mariti et in sui heredis locum venisset $3^{30}$.

Con todo, ello no es argumento suficiente para reservar el título de materfamilias a la esposa in mariti manu y calificar con el término uxor a la esposa sine manu. Este planteamiento tal vez sea debido a que el estudio sobre la evolución de este concepto no ha sido, salvo rara excepción, objeto de un análisis profundo por parte de los autores cuya mayoría se han limitado a mencionar el problema de manera marginal hasta el punto de que el propio Kaser llegó a considerarlo carente de todo interés jurídico entediendo que la cualificación de materfamilias no era sino «Ein Ehrentitel» ${ }^{3 \mathrm{I}}$.

Por fortuna algunos autores como Fulci, Clark, Kunkel, Carcaterra o Wolodkiewicz han apreciado la importancia del estudio del término realizando un enorme esfuerzo por precisar su significado y concretar su evolución ${ }^{32}$. En este sentido, a finales del siglo XIX, Fulci precisaba que el término no sólo se refería a una mujer in manu concepta, en la medida en que, de la definición de materfamilias aportada por Festo, se constata cómo en ciertos casos la mujer in manu conventa no era materfamilias porque así solamente podía ser considerada la que fuera esposa de un paterfamilias.

FESTO, De verborum significatu (Ed. Lindsay), su voz «materfamilias»: «Materfamiliae non ante dicebatur, quam vir eius paterfamiliae dictus esset; nec possunt hoc nomine plures in una familia praeter unam appellari. Sed nec vidua hoc nomine, nec quae sine filiis est, appellari potests ${ }^{33}$.

La postura restriccionista que reservaba exclusivamente tal apelativo a la esposa que se encontraba bajo la potestad del marido ha sido también acertadadamente criticada por Clark. El autor a través del análisis de las comedias plautianas de finales del siglo III a.

30 BRINI, Matrimonio e divorzio nel diritto romano, Parte prima, Il matrimonio romano, cit., págs. 37-46 y págs. 135-136, quien apoya principalmente su postura también en Boecio, In Topica, 3.14: «Tribus enim modis uxor habebatur, usu, farreo, coëmptione. Quae autem in manum per coëmptionem convenerant, eae matresfamilias vocabantur: quae vero usu vel farreo, minime. Coëmptio vero certis sollemnitatibus peragebatur, et sese in coëmendo invicem interrogabat: vir ita, an sibi mulier materfamilias esse vellet? Illa respondebat velle. Item mulier interrogabat, an vir sibi paterfamilias esse vellet? Ille respondebat velle. Itaque mulier viri conveniebat in manum, et vocabantur hae nuptiae per coëmptionem, et erat mulier materfamilias viro loco filiae. Quam sollemnitatem in suis institutis Ulpianus exponit»; Servio, In Aeneidem, 2.476: «Matrem familias dictam esse existimant quae in familia mancipioque sit patria, etsi in mariti matrimonio esset. alii matrem familias illas (dicunt) quae in matrimonium per coemptionem convenerunt); idem, II.58I: «... Materfamilias vero illa dicitur, quae in matrimonium convenit per coëmptionem: nam per quandam iuris solemnitatem in familiam migrat maritì.

3I KASER, M., Das römisches Privatrecht, I I edición, München, I955 pág. 57, afirmaba: «Materfamilias ist kein Rechtsbegriff sonder nur ein Eherentitel der uxor in manu des lebenden paterfamilias wenn Kinder in die Familie sind». No obstante en su $2^{\circ}$ edición de I97I, pág. 59 y posteriores reconoce la existencia de una pluralidad de significados del término.

${ }^{2}$ FUlCI, L., «Il divorzio nella prima epoca del diritto romano», en Archivio Giuridico Filippo Serafini, 53, I894, págs. 245 ss.; ClARK, E.C., History of Roman Private Law, III, New York, I965 págs. 79-83 (primera edición de I9I8); KunKel, W., su voz «materfamilias», en P.W.R.E., XIV, Stuttgart, I930, cols. 2183 ss.; CARCATERRA, A., «Materfamilias», en Archivio Giuridico Filippo Serafini, I23, I940, págs. II3 ss.; WolODKIEWICZ, W., «Attorno al significato della nozione di mater familias», en Studi in onore di C. Sanfilippo, III, Milano, I983, págs. 733 ss.

${ }^{33}$ FULCI, «Il divorzio nella prima epoca del diritto romano», cit., pág. 245 ss. 
C. y principios del II a. C. ${ }^{34}$, constata que al hablar de la potestad que tenía un paterfamilias de disolver el matrimonio de su hija casada sine manu, ésta venía designada tanto con el término uxor como con el término materfamilias.

PlaUto, Stichus, I.2.4I: «[Sor.]: viros nostros, quibus tu voluisti esse nos matres familias».

PlAUTO, Menaechmi, 4.I: «[Matrona]: Egone hic me patiar frustra in matrimonio,/ ubi vir compilet clanculum quidquid domist/ atque ea ad amicam deferat ? $^{35}$.

Por su parte Kunkel, en su voz de la Pauly-Wissowa Realenzyklopädie escribía en los años treinta que la noción de materfamilias era paralela a la de paterfamilias e indicaba «die römische Frau als Hausmutter und Ehegenossin des Mannes», esto es, la mujer romana, madre de la casa y esposa legítima del marido, aunque este término comenzó a usarse ya en la época clásica para indicar la mujer sui iuris ${ }^{36}$.

La estela sobre la pluralidad de significados del concepto materfamilias fue acogida una década después por Carcaterra quien, junto al primitivo significado técnicojurídico de esposa in manu, reconoció la existencia en todas las épocas de un significado social, lato y menos técnico del término como mujer de buenas costumbres o matrona que, a su juicio, presumiblemente derivaría del anterior puesto que en «una época en la que matrimonio patricio por excelencia es el matrimonio cum manu, deviene necesario que la definición jurídica de una tal uxor determine también la definición social». Sin embargo, para este autor, todas las fuentes referidas a la mujer sui iuris fueron objeto de interpolaciones, de modo que este último significado es sólo producto de la época posclásica ${ }^{37}$.

Dejando por el momento la determinanción del surgimiento del significado de materfamilias para calificar a la mujer sui iuris, en los años ochenta, Wolodkiewicz, mediante un minucioso estudio de las fuentes literarias y jurídicas, diferenció hasta seis significados distintos del término materfamilias. $\mathrm{I}^{\circ}$. Pertenencia de la esposa a la familia del marido $3^{38} ; 2^{\circ}$. Esposa que ha cumplido la coemptio ${ }^{39} ; 3^{\circ}$ Esposa de un paterfamilias que tiene $\operatorname{hijos}^{4 \circ} ; 4^{\circ}$. Mujer que tiene más de un hijo ${ }^{41} ; 5^{\circ}$. Mujer sui iuris ${ }^{42} ;$ y $6^{\circ}$. Toda esposa que

34 Sobre la datación de las comedias de Plauto, por todos, PALAdini, V.- CASTORINA, E., Storia della letteratura Latina, Bologna, I973, págs. 26 ss.; MuECKE, F., Plautus Menaechmi, Bristol, I987, pág. 5 y págs. 8-9; Von AlbRECHT, M., A History of Roman Literature, I, Leiden-New York-Köln, I997, pág. I54.

${ }^{35}$ Clark, History of Roman Private Law, III, cit., págs. 79-83.

${ }^{36}$ KUNKEL, su voz «materfamilias», cit., cols. 2183 ss.

37 CARCATERRA, «Materfamilias», cit., págs. iI3 ss.: «La mujer no casada no es apreciada en Roma (como en todas las civilizaciones primitivas) y está en condiciones de inferioridad respecto a aquélla casada. Tanto es verdad que 'matrona', la mujer por excelencia, deriva etimológicamente de 'mater'».

${ }^{38}$ Cicerón, Topica, 3.I4; Aulo Gellio, Noctes Atticae, i8.6.9.

39 Boecio, In Topica, 3.14.

${ }^{4 \circ}$ Festo, De verborum significatu, s.v. «materfamilias».

${ }^{4 \mathrm{I}}$ Aulo Gellio, Noctes Atticae, 5.I9.9: «... Eius rogationis verba haec sunt: 'Velitis, iubeatis, uti L. Valerius L. Titio tam iure legeque filius siet, quam si ex eo patre matreque familias eius natus esset, utique ei vitae necisque in eum potestas siet, uti patri endo filio est. Haec ita, uti dixi, ita vos, Quirites, rogo»; idem, I8.6.4; Nonio Marcelo, De compendiosa doctrina, sub «matronae et matris 
vive conforme a los boni mores, -en cuyo caso también se la conoce con el apelativo de matrona-, o toda mujer, incluso soltera o viuda, que vive según las buenas costumbres ${ }^{43}$.

Entre esta pluralidad de significados dos, en su opinión, se contraponen sustancialmente: aquél de esposa integrada en la familia agnaticia de su marido y aquél de mujer sui iuris. Junto a ellos, acogiendo la teoría de Carcaterra, defiende la existencia en todas las épocas del Derecho romano de una noción social de materfamilias referida a la mujer honesta o matrona, aunque sin derivar esta noción del significado jurídico de uxor in $m a n u^{44}$.

En efecto, son copiosos los documentos literarios de época republicana que califican a la mujer de buenas costumbres de materfamilias o matrona:

PlauTo, Mercator, vs. 403-406: «[Dem]: Labefacto paulatim. Verum quod praeterii dicere,/ neque illa matrem satis honeste tuam sequi poterit comes,/ neque sinam. [Char]: Qui vero?. [Dem]: Quia illa forma matrem familias».

CiCERón, Pro Caelio, 32: «...quos intellegebant non communi condicione servitutis uti sed licentius liberius familiariusque cum domina vivere? Quis enim hoc non videt, iudices, aut quis ignorat, in eius modi domo in qua mater familias meretricio more vivat, in qua nihil geratur quod foras proferendum sit...» 45 .

Asimismo, dicho significado es constatado en numerosas fuentes literarias y jurídicas de época clásica y postaclásica, entre las que descatan un pasaje de Suetonio y otro de Ulpiano:

Suetonio, Augustus, 69.I: «Adulteria quidem exercuisse ne amici quidem negant, excusantes sane non libidine, sed ratione commissa, quo facilius consilia adversariorum per cuiusque mulieres exquireret. $M$.

familiae»: «matrem familias (dictam esse existimant) quae in familia mancipioque sit patria, etsi in mariti matrimonio esset»; Isidoro de Sevilla, Etymologie, 9.59: «Matres familias quia per quandam iuris solemnitatem in familia mariti transierunts.

${ }^{42}$ Ulpianus, Regulae, 4.I.

${ }^{43}$ D. 50.I6.46.I. WOLODKIEWICZ, «Attorno al significato della nozione di mater familias», cit., págs. 733 ss. Sobre los distintos significados de materfamilias, RIVIER, Précis du Droit de famille romain, cit., pág. I62 y pág. I66; PARIBENI, La famiglia romana, cit., págs. 36-37; CREMADESPARICIO, «Dos et virtus». Devolución de la dote y sanción a la mujer romana por sus malas costumbres, cit., pp., I6 ss.; GAUDEMET, J., «Le status de la femme dans l'Empire romain», en Études de droit romain, vol. III, Camerino, I979, págs. 242-243; CASTRESANA, Catálogo de virtudes femeninas, cit., págs., 33 ss. y págs. 49 ss.; FERNÁNDEZ BAQUERO, Repudium-Divortium (Origen y configuración jurídica hasta la legislación matrimonial de Augusto), cit., págs. 327-329; PATRIZIA, G., «Mores e interpretatio prudentium nella definizione di Materfamilias (una qualifica fra conventio in manum e status di sui iuris)», en Nozione, Formazione e Interpreazione del diritto dall'età romana alle esperienze moderne. Ricerche dedicate al professor Filippo Gallo, I, Napoli, I997, págs. 30I-338; RomANo, Matrimonium iustum. Valori economici e valori culturali nella storia giuridica del matrimonio, cit., págs. 80 ss.; GIUNTI, P., Consors Vitae. Matrimonio e ripudio in Roma antica, Milano, 2004, págs. 304 Ss. y la bibliografía específica por ellos citada.

${ }^{44}$ WOLODKIEWICZ, «Attorno al significato della nozione di mater familias», cit., págs. 733 ss.

${ }^{45}$ Vid., también, Plauto, Stichus, vs. I03-I05: «[Ant.]: Vostrum animum adhiberi volo:/ nam ego ad vos nunc imperitus rerum et morum mulierum,/ discipulus venio ad magistras: quibus matronas moribus;/ quae optumae sunt, esse oportet?' Sed utraque ut dicat mihi»; idem, Poenulus, v. 32: «matronae tacitae spectunt, tacitae rideant».

Redur 4 / 2006 


\begin{abstract}
Antonius super festinatas Liviae nuptias obiecit et feminam consularem e triclinio viri coram in cubiculum abductam, rursus in convivium rubentibus auriculis incomptiore capillo reductam; dimissam Scriboniam, quia liberius doluisset nimiam potentiam paelicis; condiciones quaesitas per amicos, qui matres familias et adultas aetate virgines denudarent atque perspicerent, tamquam Toranio mangone vendente. Scribit etiam ad ipsum haec familiariter adhuc necdum plane inimicus aut hostis: "Quid te mutavit?' Quod reginam ineo?' Uxor mea est. Nunc coepi an abhinc annos novem?' Tu deinde solam Drusillam inis? Ita valeas, uti tu, hanc epistulam cum leges, non inieris Tertullam aut Terentillam aut Rufillam aut Salviam Titiseniam aut omnes. An refert, ubi et in qua arrigas.?"».
\end{abstract}

D. 50.16.46』I (Ulpianus libro LIX. Ad Edictum): «Materfamilias» accipere debemus eam, quae non inhoneste vixit; matrem enim familias a ceteris feminis mores discernunt, atque separant; proinde nihil intererit, nupta sit, an vidua, ingenua sit, an libertina; nam neque nuptiae, neque natales faciunt matremfamilias, sed boni mores ${ }^{46}$.

En consecuencia, a la vista del análisis de las fuentes resulta evidente que, al menos desde mediados de la época republicana, en la que seguían siendo frencuentes los matrimonios acompañados de la conventio in manum, con el término materfamilias tanto se podía designar a la mujer in mariti manu como a aquélla otra que fuese honesta porque su vida se adecuaba a los boni mores, esto es, matrona, a la que se contraponen con frecuencia los términos paelex o meretrix que hacen referencia a la mujer carente de honestidad, esté casada, soltera o sea viuda ${ }^{47}$.

${ }^{46}$ Cfr. asimismo, Aulo Gellio, Noctes Atticae, I.23.8-I2: «Tum puer matre urgente lepidi atque festivi mendacii consilium capit. Actum in senatu dixit, utrum videretur utilius exque republica esse, unusne ut duas uxores haberet, an ut una apud duos nupta esset. Hoc illa ubi audivit, animus compavescit, domo trepidans egreditur ad ceteras matronas. Pervenit ad senatum postridie matrum familias caterva; lacrimantes atque obsecrantes orant, una potius ut duobus nupta fieret, quam ut uni duae. Senatores ingredientes in curiam, quae illa mulierum intemperies et quid sibi postulatio istaec vellet, mirabantur. Puer Papirius in medium curiae progressus, quid mater audire institisset, quid ipse matri dixisset, rem, sicut fuerat, denarrat»; Gayo, Institutae, 3.220: «Iniuria autem committitur... quis matrem famlias aut praetextatum adsectatus fuerit...»= Institutae Iustiniani, 4.4; D. 43.30.3『6 (Ulpianus libro LXXI. Ad Edictum): In hoc interdicto, donec res iudicetur, feminam, praetextatum, eumque, qui proxime praetextati aetatem accedet, iterim apud matremfamilias deponi Praetor iubet. Proxime aetatem praetextati accedere eum dicimus, qui puberem aetatem nunc ingressus est. Quum audis matremfamilias, accipe notae auctoritatis feminam.

${ }^{47}$ Respecto a la contraposición entre mujer honesta, es decir, materfamilias o matrona y mujer no honesta, esto es, paelex o meretrix, vid., entre otros, Plauto, Mostellaria, v. I90: «[Sc.]: matronae, non meretricium est unum inservire amantem»; idem, Cistellaria, vs. 78-80: «[Lena]: Matronae magis conducibilest istuc, mea Selenium,/ unum amare et cum eo aetatem exigere quoi nuptast semel./ verum enim meretrix fortunate est oppidi simillima:/ non potest suam rem obtinere sola sine multis viris»; idem, Miles gloriosus, vs. 789-793: "[Per.]: Habeo eccillam meam clientam, meretricem adulescentulam./ sed quid ea usus est?'/ [Pal.]: Ut ad te eam iam deducas domum/ itaque eam huc ornatam adducas, ex matronarum modo/ capite compto, crinis vittasque habeat, adsimuletque se/ tuam esse uxorem: ita praecipiumdum est»; Terencio, Adelphos, v. 747: «[De.] Quid igitur facies?' [Mi.] Domi erit. [De.] Pro diuom fidem,/ meretrix et materfamilias una in domo.3;; Tito Livio, Ab urbe condicta, 39.53.3: «Demetrium ut pacis auctorem cum ingenti fauore conspiciebant, simul et spe haud dubia regnum ei post mortem patris destinabant. nam etsi minor aetate quam Perseus esset, hunc iusta matre familiae, illum paelice ortum esse; illum ut ex uulgato corpore genitum nullam certi patris notam habere, hunc insignem Philippi similitudinem prae se ferre. ad hoc Romanos Demetrium in paterno solio locaturos...»; D. 47.IO.I5』I5 (Ulpianus libro

Redur 4 / 2006 
Mayor problema presenta la concreción del momento en que desaparece el significado más antiguo de materfamilias como esposa in manu y aparece la noción de materfamilias como mujer sui iuris. Se trata sin duda, de un significado posterior al de mujer de buenas costumbres o matrona porque las fuentes solamente hacen referencia al mismo a partir de la época imperial siendo, por tanto, el resultado de un momento histórico posterior, probablemente consecuencia de esa mayor capacidad jurídica y de obrar adquirida por la mujer ${ }^{48}$.

En este ámbito digno de mención es el parangón que efectúa Ulpiano en dos de sus fragmentos entre paterfamilias y materfamilias, indicando que ambos están sujetos a su propia potestas.

Ulpiano, Regulae, 4.I.: Sui iuris sunt familiarum suarum principes, id est pater familiae itemque mater familiae.

D. I.6.4 (Ulpianus libro I. Institutionum): Nam civium Romanorum quidam sunt patresfamiliarum, alii filiifamiliarum, quaedam matresfamiliarum, quaedam filiaefamiliarum. Patresfamiliarum sunt, qui sunt suae potestatis, sive puberes, sive impuberes; simili modo matresfamiliarum.

Frente a las posturas que, como Carcaterra ${ }^{49}$, consideran de intervención justinianea el empleo de materfamilias en este sentido, convenimos con Kunkel y Wolodkiewicz en lo infundado de esta postura, siendo ampliamente numerosos los fragmentos de juristas clásicos recogidos en el Digesto que designan con el calificativo de materfamilias a la mujer sui iuris, con relación a específicos actos jurídicos, como en sede testamentaria $^{50}$, en materia de injurias ${ }^{51}$ o respecto a la dote ${ }^{52}$, por citar algunos, sin que haya quedado suficientemente demostrada la existencia de interpolaciones en todos ellos ${ }^{53}$.

LXXVII. Ad edictum): Si quis virgines appellasset, si tamen ancillari veste vestitas, minus peccare videtur, multo minus si meretricia veste feminae, non matrumfamiliarum vestitae fuissent; si igitur non matronali habitu femina fuerit, et quis eam appellavit, vel ei comitem abduxit, iniuriarum tenetur, D. 48.2.3『3 (Paulus libro III. De Adulteriis): Sed et si aliud crimen obiiciat, veluti quod domum suam praebuit, ut struprum materfamilias pateretur, quod adulterum deprehensum dimiserit, quod pretium pro comperto strupro acceperit, et si quid simile, id ipsum libellis comprehendendum erit, D. 48.5.IO (Papinianus libro II. De Adulteriis): Mater autem familias significatur non tantum nupta, sed etiam vidua.

$4^{8}$ Al respecto, FERNÁNDEZ BAQUERO, Repudium-Divortium (Origen y configuración jurídica hasta la legislación matrimonial de Augusto), cit., págs. 327-329.

49 CArCATERra, «Materfamilias», cit., págs. I59-I60; Lenel, O., Palingenesia Iuris Civilis, 2, Leipzig, I889 (reimp. ampl. Graz I960, reimp. Aalen 2000), pág. 928, considera interpolado «simili modo matres familiarum»; SCHULZ, F., «Die Epitome Ulpiani des Codex Vaticanus Reginae, II28», en Jurist. Texte $f$. Vorles. und Üb., 3, I926, pág. 29 considera la noción de marterfamilias en estos pasajes como «Ganz sicher unklassich».

${ }^{50} C f$ r., por ejemplo, D. I.7.25 pr (Ulpianus libro V. Opinionum): Post mortem filiae suae, quae ut materfamilias quasi iure emancipata vixerat et testamento scriptis heredibus decessit, adversus factum suum, quasi non iure eam nec praesentibus testibus emancipasset, pater movere controversiam prohibetur, D. 35.2.86 (Iulianus libro XL. Digestorum): Titia testamento suo Titium, fratrem suum, ex parte tertia heredem instituit, fideique eius commisit, ut hereditatem retenta quarta parte Secundae et Proculae restituat; eadem fratri quaedam praedia praelegavit: quaero, an Titus ea, quae praelegata sunt etiam pro ea parte hereditatis, quam rogatus est restituere, an integra retinere debeat. Respondi, Titium legata integra retinere debere, sed in partem quartam imputari oportere duodecimam partem praediorum; sed si non esset adiectum, ut pars quarta deduceretur, totum trientem praediorum legi Falcidiae imputari oportere, quoniam contra sententiam matris familiae lex Falcidia induceretur, D. 38.I7.I pr-『I (Ulpianus libro XII. Ad Sabinum): Sive ingenua,

Redur 4 / 2006 
Estos pasajes de Ulpiano, Juliano, Africano y Q.C. Escévola, que vivieron y escribieron sus obras en el siglo II y principios del III d. C., ponen de manifiesto que el significado más antiguo de materfamilias como mujer in mariti manu fue sustituido en época clásica por uno nuevo, pasando a desginar jurídicamente a la mujer sui iuris, teoría que, a juicio de Wolodkiewicz, viene confirmada por la distinta terminología empleada por Gellio, Próculo y Gayo en materia de adrogatio dado que, mientras los dos primeros seguían utilizando el término materfamilias con el significado de uxor in mariti manu, -al indicar que la situación del arrogado era idéntica a la de los nacidos de un matrimonio en virtud del cual la esposa era llamada materfamilias ${ }^{4}-$, Gayo, por el contrario, no usa la expresión «ex matre familias natus», sino que aclara que la adrogatio es llamada así porque «al adoptante se le pregunta si quiere que sea hijo suyo legítimo el que va a ser adoptado» ${ }^{55}$.

En tiempos de Gayo, el matrimonio acompañado de la conventio in manum estaba prácticamente extinguido ${ }^{56}$, siendo destacable que el jurista no utilice nunca el término

sive libertina mater est, admitti possunt liberi ad hereditatem eius ex Senatusconsulto Orphitiano. Si ea sit mater, de cuius statu dubitatur, utrum materfamilias sit, an filiasfamilias, utputa quoniam pater eius ab hostibus captus sit, si certum esse coeperit, matremfamilias esse, liberi admittentur. Unde tractari potest, an medio tempore, dum status pendet, succurri iis per Praetorem debeat, ne, si medio tempore decesserint, nihil ad heredem transmittant. Et magis est, ut subveniatur, ut in multis casibus placuit.

${ }^{51}$ Vid., al respecto, D. 47.Io.I $\ 3$ (Ulpianus libro LVI. Ad Edictum): Item aut per semet ipsum alicui fit iniuria, aut per alias personas; per semet, quum directo ipsi cui patrifamilias vel matrifamilias fit iniuria, per alias, quum per consequentias fit, quum fit liberis meis vel servis meis, vel uxori nuruive. Sobre el concepto de materfamilias en el edicto de adtemptata pudicitia, cfr. GUERRERO, M., «La idea de materfamilias en el edictum de adtemtata pudicitia», en LóPEZ RosA, E.Del Pino, F., El Derecho de Familia: De Roma al Derecho Actual, Huelva, 2004, págs. 297 ss.

${ }^{52}$ D. 24.3.30 pr-I (Iulianus libro XVI. Digestorum): Nupta non impeditur, quominus cum priore marito de dote experiatur. Quoties culpa viri accidit, ne dos a socero aut a quolibet alio, qui mulieris nomine promiserat, exigeretur, si aut in matrimonio filia decesserit, aut materfamilias facta eum, qui dotem repromiserat, heredem instituerit, satis constat, nihil amplius virum praestare debere, quam ut eos obligatione liberet, D. 24.3.34 (Africanus, libro VIII. Quaestionum): Titia divortium a Seio fecit; hanc Titius in sua potestate esse dicit, et dotem sibi reddi postulat: ipsa se matremfamilias dicit et de dote agere vult: quaesitum est, quae partes iudicis sint? Respondi, patri, nisi probet, filiam non solum in sua potestate esse, sed etiam consentire sibi, denegandam actionem, sicuti denegaretur, etiamsi constaret eam in potestate esse; D. 32.4I.7 (Scaevola, libro XXII. Digestorum): ...Quaesitum est, quum puella non ex causa legati pecuniam in dotem ab heredibus patris acceperat, sed mortuo secundo marito materfamilias facta dotem recuperaverat...

53 KUNKEL, su voz «materfamilias», cit., cols. 2183 ss.; WOLODKIEWICZ, «Attorno al significato della nozione di mater familias», cit., págs. 74I ss.; BonfanTE, Corso di Diritto romano, Volume primo, cit., pág. I3; FERNÁNDEZ BAQUERO, Repudium-Divortium (Origen y configuración jurídica hasta la legislación matrimonial de Augusto), cit., págs. 327-329.

${ }^{54}$ Aulo Gellio, Noctes Atticae, 5.I9.9 (vid. n. 4I del presente trabajo); D. I.7.44 (Proculus libro 8 Epistolarum): Si is, qui nepotem ex filio habet, in nepotis loco aliquem adoptavit, non puto, mortuo avo iura consanguinitatis inter nepotes futura esse, sed si sic adoptavit, ut etiam iure legis nepos suus esset, quasi ex Lucio puta filio suo, et ex matrefamilias eius natus esset, contra puto.

55 GAYo, Institutae, I.99: «Populi auctoritate adoptamus eos, qui sui iuris sunt; quae species adoptionis dicitur adrogatio, quia et is, qui adoptat, rogatur, id est interrogatur, an uelit eum quem adoptaturus sit iustum sibi filium esse; et is, qui adoptatur, rogatur, an id fieri patiatur; et populus rogatur, an id fieri iubeats.

${ }^{56}$ FERNÁNDEZ DE BUJÁN, «Reflexiones a propósito de la realidad social, la tradición jurídica y la moral cristiana en el matrimonio romano (I)», cit., pág. 3. En efecto, el usus vigente acaso en época de Cicerón (pro Flacco, 34.84), era un instituto completamente en desuso en tiempos de Gayo (Institutae I.III). La confarreatio comenzó a decaer a comienzos del Principado y desde el reinado de Tibero, tras el senadoconsulto ex relatione maximi et Tuberonis, producía sólo efectos sacrales sin 
materfamilias para indicar a la mulier in manum mariti, sino que emplea otras expresiones descriptivas («esposa sobre la que el marido tiene la manus»; «esposa que se encuentra en la situación de una persona filiae locos $)^{57}$, lo cual constituye un importante indicio para afirmar que la vieja noción de materfamilias=uxor in mariti manu, había ya probablemente desparecido en la segunda mitad del siglo I o en la primera mitad del siglo II d. $\mathrm{C}^{58}$.

V. Regulación actual y conclusión.

Hoy en día, afortunadamente, ha quedado obsoleta la originaria noción de matrimonium que, según D'Ors, consideraba la relación matrimonial desde el punto de vista del esposo que adquiría como mujer una mater para su casa ${ }^{59}$. En efecto, en la actualidad los cónyuges son iguales en derechos y deberes (art. 66 Código Civil), deben respetarse y ayudarse mutuamente, así como actuar en beneficio de la familia (art. 67 Código Civil), correspondiendo a ambos progenitores la patria potestad sobre los hijos no emancipados (art. I54 Códogo Civil) ${ }^{60}$, de acuerdo con la nueva redacción establecida por la Ley I3/2005, de I de julio, que modificó el Código Civil en materia de derecho a contraer matrimonio, reconociendo tal derecho a las parejas del mismo sexo cuya relación conyugal, al menos, se sustenta también sobre los principios de igualdad, respeto y ayuda mutua.

Continúa siendo, por tanto, de extraordinaria relevancia analizar el papel de los progenitores en el conjunto de deberes y facultades que nuestro ordenamiento les concede sobre los hijos no emancipados a través de la patria potestad, sin olvidar que la misma también puede adquirirse ex iure, es decir, al margen biológico de la procreación a través de la adopción (arts. I75 y ss. Código Civil).

provocar la sumisión de la mujer a la potestad del marido (Gayo, Institutae, I.I36; I.II2; Táctico, Annales, 4.I6). La coemptio, en cambio, tuvo una mayor duración porque podía realizarse no sólo matrimonii causa, sino también fiduciae causa, siendo usada para cambiar de tutor, para provocar la extención de los sacra o para dar la posibilidad a la mujer sui iuris de hacer testamento. En tiempos de Gayo, la coemptio matrimonii causa existía todavía (Institutae, I.II3). En cambio de las coemptiones fiduciae causa existía solamente la coemptio tutelae evitandae causa. Al respecto, vid. la bibliografía citada en las ns. 20-22 del presente trabajo.

${ }^{57}$ Así, GAYO, Institutae, I.II4; 7.III, etc.

${ }^{58}$ WolOdKIEWICZ, «Attorno al significato della nozione di mater familias», cit., págs. 753 .

59 «Ducit uxorem»=«se lleva una mujer legítima». D’ORS, Derecho privado romano, cit., pág. 293. Por contra, afirma el autor, el término «Nuptiae (siempre en plural) se refiere a la situación de la mujer casada, pues sólo de la mujer se dice que es nubilis ('casadera'), que nubet ('se casa') o es nupta ('casada')». Sobre los significados de matrimonium y nuptiae, BRINI, Matrimonio e divorzio nel diritto romano, Parte prima, il matrimonio romano, cit., págs. I46-I48; DAZA MARTíNEZ, «'Nuptiae' et 'matrimonium'», cit., págs. 57 ss.; ORTEGA CARRILlO DE Albornoz, A., «Precisiones terminológicas: Nuptias y Matrimonium», en Revista General de Derecho Romano, (www.iustel.com), n⿳0 5, 2005, págs. I ss.; FERNÁNDEZ DE BUJÁN, «Reflexiones a propósito de la realidad social, la tradición jurídica y la moral cristiana en el matrimonio romano (I)», cit., pág. I.

6o Actualmente la patria potestad sobre los hijos no emancipados, conforme al artículo I54 del Código Civil, comprende los siguientes deberes y facultades:

«I. Velar por ellos, tenerlos en su compañia, alimentarlos, educarlos y procurarles una formación integral.

2. Representarlos y administrar sus bienes.

Si los hijos tuvieren suficiente juicio deberán ser oídos siempre antes de adoptar deciesiones que les afecten.

Los padres podrán en el ejercicio de su potestad recabar el auxilio de la autoridad. Podrán también corregir razonable y moderadamente a los hijos».

Redur 4 / 2006 
Y en dicho análisis conviene evocar al proceso histórico-jurídico de una evolución que parte de esa primitiva noción de patria potestas que permitía al paterfamilias, esto es, a quien no estaba sometido a potestad ajena decidir incluso sobre la vida muerte de sus filii cuyo vínculo podía constituirse al margen biológico puesto que lo que primaba eran las relaciones agnaticias y no las cognaticias. Impera memorar que el mayor peso de éstas últimas, unida a la mayor capacidad patrimonial de los hijos, contribuyeron a la consideración de la patria potestad más como un deber que como un derecho. Y a todo ello, debemos añadir la mayor capacidad jurídica y de obrar de las mujeres como consecuencia y/o efecto del incremento de los matrimonios no acompañados de la conventio in manum, gracias a los cuales la esposa no quedaba sometida a la potestad del marido o del paterfamilias del esposo alieni iuris. La estrecha relación entre ambos ha dado origen a una serie de incorrectas interpretaciones doctrinales, algunas de las cuales hemos apuntado en este trabajo, como la de limitar el calificativo de materfamilias a la esposa in manu conventa puesto que, como constata el análisis de las fuentes efectuado, desde mediados de la época republicana, este término también se refería a la mujer de buenas costumbres con independencia de su estado civil, significado al que se añadió, a partir de la época clásica, aquél de mujer sui iuris, esto es, de mujer sometida a su propia potestad y que, desde esta perspectiva, es perfectamente trasladable a nuestro derecho positivo. 